\title{
Reproductive phenological pattern of Calotropis procera (Apocynaceae), an invasive species in Brazil: annual in native areas; continuous in invaded areas of caatinga
}

\author{
Mellissa Sousa Sobrinho ${ }^{1}$, George Machado Tabatinga ${ }^{1}$, Isabel Cristina Machado ${ }^{1}$ and Ariadna Valentina Lopes ${ }^{1,2}$
}

Submitted: 5 September, 2012. Accepted: 23 December, 2012

\begin{abstract}
In this study, we evaluated the phenological patterns (vegetative and reproductive) of Calotropis procera (Apocynaceae-Asclepiadoideae) in Brazil, comparing its phenology in an area where it is invasive with that observed in areas to which it is native. Phenological observations were carried out over a 24 -month period at sites in and around areas of caatinga (shrublands). We estimated the relative frequency of each phenophase, and we documented a dramatic difference between phenophases in terms of the pattern of reproductive phenology. The pattern of continuous flowering and fruiting observed in the invaded area strongly diverges from the 2- to 6-month flowering and fruiting period of the annual pattern. The continuous pattern of reproduction seems to have facilitated the invasion of the Brazilian caatinga by C. procera.
\end{abstract}

Key words: Asclepiadoideae, flowering, fruiting, life history, phenological plasticity

In some tropical plant species, the flowering pattern remains consistent under a wide range of environmental conditions, whereas that of other species can change drastically among ecosystems (Newstrom et al. 1994). Plasticity in phenology contributes to making a species dominant (Devineau 1999), in particular for invasive species (Seghieri \& Simier 2002). However, studies on the phenology of invasive species are scarce, most having been conducted in greenhouses (e.g., Weber \& Schmid 1998; Kollmann \& Bañuelos 2004) or in temperate regions (e.g., Perglová et al. 2006), only a few having been carried out in the tropics (e.g., Seghieri \& Simier 2002). Comparisons of the phenological timing of a species between native and invaded areas are even rarer (see Pasiecznik et al. 2006; Godoy et al. 2009). Although some studies using biological attributes as predictors of invasiveness have focused on fruiting or flowering (Reichard \& Hamilton 1997; Lake \& Leishman 2004), that information comes from non-systematic compilations of phenological data. Here, we aimed to evaluate the phenological patterns (vegetative and reproductive) of Calotropis procera (Aiton) W.T. Aiton (Apocynaceae-Asclepiadoideae) in an area in which it is invasive, in comparison with those observed in areas to which it is native.
Calotropis procera is native to Africa and Asia, occurring in an arc extending from the coasts of Senegal and Mauritania in northwest Africa, through the Arabian Peninsula, Afghanistan and Pakistan into India (Parsons \& Cuthbertson 2001). Introduced in Brazil as an ornamental more than a century ago, it became invasive, spreading across several states, most of them in the northeastern region of the country. The species is an evergreen shrub, 2-4 $\mathrm{m}$ in height; the flowers are hermaphrodite and melittophilous; and the fruits are follicles, the seeds having long silk threads and being wind-dispersed. The study was carried out from August 2006 to July 2008 at sites in and around areas of caatinga (shrublands) within the Serra Talhada Experimental Station ( $07^{\circ} 59^{\prime} 00^{\prime \prime} S$; $\left.38^{\circ} 19^{\prime} 16^{\prime \prime} \mathrm{W}\right)$, located in the municipality of Serra Talhada, in the state of Pernambuco, Brazil. The rainy season in the area is from January to May. Mean annual temperature and rainfall are $24.5^{\circ} \mathrm{C}$ and $693.9 \mathrm{~mm}$, respectively (climate data obtained from the Pernambuco Institute of Technology/Meteorology Laboratory of Pernambuco).

Phenological observations were carried out monthly in 17 adult individuals $30-50 \mathrm{~m}$ apart. We recorded the total number of branches and the number of branches exhibiting

\footnotetext{
${ }^{1}$ Universidade Federal de Pernambuco, Departamento de Botânica, PE, Brazil

${ }^{2}$ Author for correspondence: avflopes@ufpe.br
} 
the following phenophases: sprouting (leaf flush); flowering (including buds); and fruiting (green or ripe). To estimate the relative frequency of each phenophase in the population-i.e., the intensity level sensu Fournier (1974) - the number of branches in each phenophase was divided by the total number of branches and multiplied by 100 . In addition, the activity index (AI) was calculated by observing the presence/absence of each reproductive phenophase per individual, and we used those data in order to calculate the proportion of individuals in the population displaying each phenophase (sensu Bencke \& Morellato 2002a). The AI can also be used in order to evaluate intraspecific synchrony, a larger proportion of individuals in a given phenophase at the same time indicating greater synchrony in the population (Bencke \& Morellato 2002b). Phenological patterns were determined following Newstrom et al. (1994). Spearman's correlations coefficients $\left(\mathrm{r}_{\mathrm{s}}\right)$ were calculated in order to determine whether flowering/fruiting intensity correlates with the amount of rainfall (monthly total) and with temperature (monthly average).

During the two-year period of phenological observation, $C$. procera was evergreen. Flowering and fruiting were continuous and relatively consistent (Fig. 1). The flowering individuals showed AIs that were consistently high, ranging from $76.5 \%$ to $100 \%$, indicating a high degree of syn- chrony among individuals (>60\%). Intensity levels were highest in the beginning of the dry season-with peaks in August 2006 (73.8\%) and September 2007 (56.7\%)-and were lowest in December 2006 and December 2007 (21\% and $17 \%$, respectively). Fruiting peaks were observed in September 2006 (AI: 100\%; intensity: 66.2\%) and October 2007 (AI: 100\%; intensity: 64.8\%), during the dry season and just after flowering peaks, the lowest AIs and intensity levels being observed in the rainy months (AI: $64.7 \%$ and 52.9\% in February 2007 and January 2008, respectively; intensity: 16.5\% and 9.7\% in January 2007 and January 2008, respectively), as shown in Fig. 1. Fruiting was also highly synchronised among individuals, except in January 2008 (52.9\%). Flowering correlated negatively with temperature $\left(\mathrm{r}_{\mathrm{s}}=-0.64, \mathrm{p}=0.0008\right)$, and fruiting negatively correlated with rainfall $\left(r_{s}=-0.57, p=0.003\right)$. No other significant correlations were observed.

Calotropis procera has also been shown to have an evergreen leafing pattern in the deserts of Saudi Arabia (El-Ghani 1997). In the caatinga, most of the native species are deciduous, evergreen species accounting for only approximately $18 \%$ (Barbosa et al. 2003). The deep root system of $C$. procera, with a long main axial root (Parsons \& Cuthbertson 2001), is similar to that observed in many evergreen species that are native to the caatinga (Barbosa

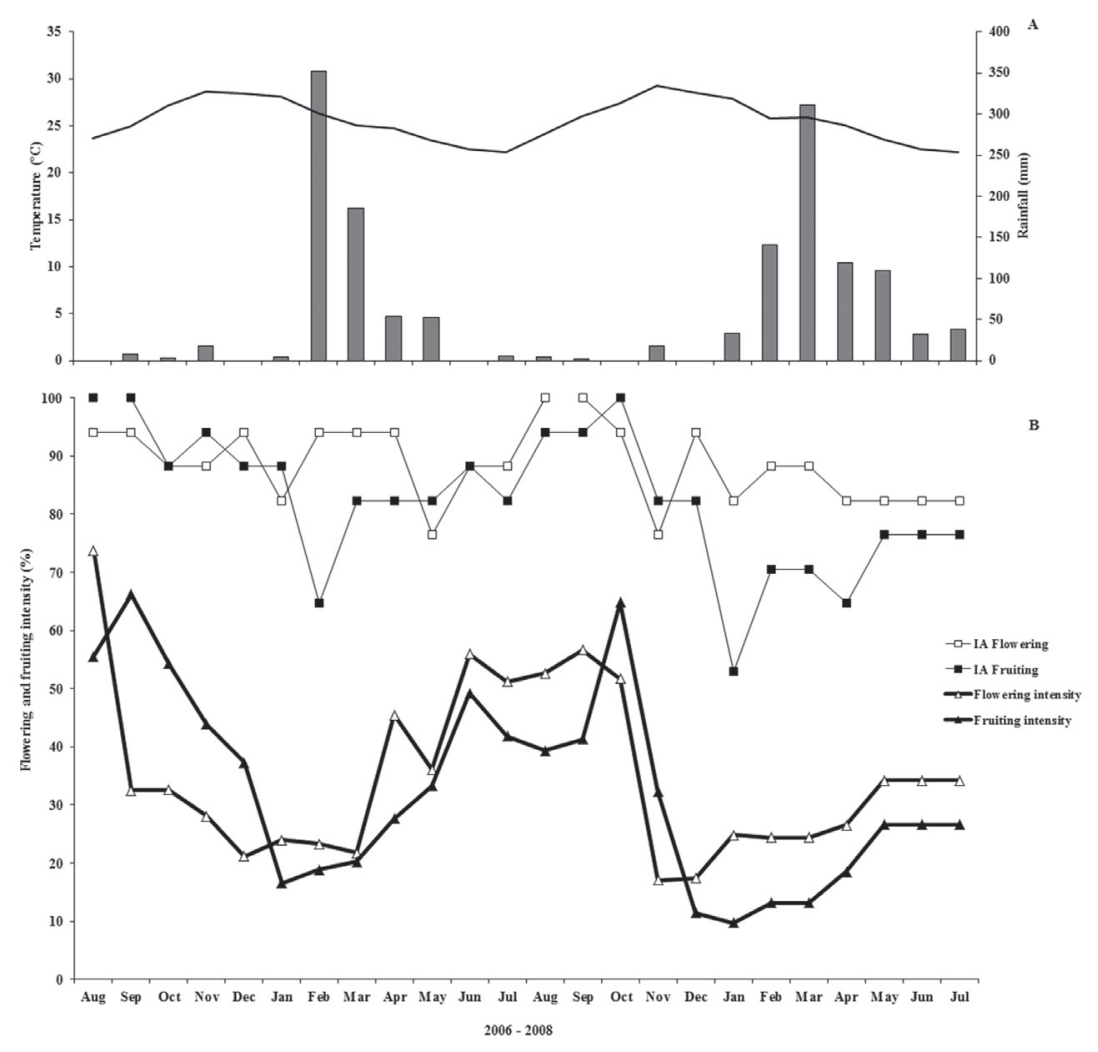

Figure 1. (A) Monthly temperature (line) and rainfall (bars) in the municipality of Serra Talhada, in the state of Pernambuco, Brazil, between August 2006 and July 2008. (B) Intensity of flowering (including flower buds), intensity of fruiting, and activity indices (AIs) for Calotropis procera in Serra Talhada, where the species is invasive, during the same period. 
et al. 2003). The continuous flowering observed for $C$. procera in the present study strongly diverges from what has been observed in its native areas in India (Singh \& Yadava 1974), Israel (Eisikowitch 1986) and Saudi Arabia (El-Ghani 1997). In Israel, flowering has been reported to occur for six months, during the spring and summer, with possible slight variations resulting from temperature fluctuations (Eisikowitch 1986). In fact, the distribution of C. procera in Israel was shown to be drastically restricted by thermal conditions due to its "thermophilic" nature (Eisikowitch 1986). In Saudi Arabia, flowering was found to start early in the spring, when temperatures are still mild, last for four months, and finish two or three weeks before the arrival of the highest temperatures, which are usually around $50^{\circ} \mathrm{C}$ (El-Ghani 1997). In India, the species was also found to flower annually, for two months during the summer (Singh \& Yadava 1974). In those studied areas, temperatures vary widely throughout the year, and extremely high temperatures occur in some desert areas. In contrast, the mean annual temperature in the caatinga is approximately $26^{\circ} \mathrm{C}$ and temperatures vary little over the course of the year (e.g., Machado et al. 1997; Barbosa et al. 2003). Thus, temperature seems to explain the phenological changes observed in C. procera in invaded areas. In phenological studies with native, typical woody caatinga species, flowering patterns, conversely, have been shown to be more strongly affected by rainfall, most of them flowering during the rainy season (Machado et al. 1997; Barbosa et al. 2003), except for the evergreens, $60 \%$ of which flower during the dry season (Barbosa et al. 2003). Nevertheless, none of those studies registered any species with continuous flowering, as observed for $C$. procera. Long flowering periods were found to be an important attribute for invasive species in Canada (Goodwin et al. 1999) and in the Mediterranean, because they increased the chances of reproductive success (Lloret et al. 2005). This is an advantage over native species that exhibit seasonal flowering and strong competition for pollinators. Those findings support the hypothesis that invasive species with functional characteristics qualitatively different from the native flora are successful invaders.

Phenological plasticity seems to be an essential attribute for the successful maintenance of invasive plants (Seghieri \& Simier 2002). In addition to the changes in the reproductive phenological pattern, C. procera showed a suite of traits that are associated with invasiveness in tropical ecosystems, such as large leaves (e.g., Lloret et al. 2005), wind-dispersed seeds (e.g., Lake \& Leishman 2004), hermaphrodite flowers (e.g., Reichard \& Hamilton 1997), and attractiveness to humans (e.g., Cox 2004), initially as an ornamental and currently as a forage plant. The presence of all those life history attributes, combined with the observed reproductive phenological changes, might have facilitated the success of $C$. procera in the invasion process and reveal its potential to invade other ecosystems in the world.

\section{Acknowledgements}

We are grateful to the Instituto Agronômico de Pernambuco (IPA, Agronomy Institute of Pernambuco), especially to the staff of its Experimental Station at Serra Talhada, for authorizing our fieldwork. The study received financial support in the form of grants from the Fundação de Amparo à Ciência e Tecnologia do Estado de Pernambuco/(Brazilian) Coordenação de Aperfeiçoamento de Pessoal de Nível Superior (FACEPE/CAPES, Foundation for the Support of Scientific and Technological Development of the state of Pernambuco/ Office for the Advancement of Higher Education; doctoral grant to MSS), CAPES (master's scholarship grant to GMT), and the Brazilian Conselho Nacional de Desenvolvimento Científico e Tecnológico (CNPq, National Council for Scientific and Technological Development; research grants to AVL and ICM). Fieldwork was partially funded by the CAPES Programa Nacional de Cooperação Acadêmica (Procad, National Program of Academic Cooperation; Grant no. 0166057).

\section{References}

Barbosa, D.C.A.; Barbosa, M.C.A. \& Lima, L.C.M. 2003. Fenologia de espécies lenhosas da Caatinga. Pp. 657-693. In: Leal, I.R.; Tabarelli, M. \& Silva, J.M.C. (Orgs.). Ecologia e conservação da Caatinga. Recife, Editora Universitária da UFPE.

Bencke, C.S.C. \& Morellato, L.P.C. 2002a. Comparação de dois métodos de avaliação da fenologia de plantas, sua interpretação e representação. Revista Brasileira de Botânica 25: 269-275.

Bencke, C.S.C. \& Morellato, L.P.C. 2002b. Estudo comparativo da fenologia de nove espécies arbóreas em três tipos de floresta atlântica no sudeste do Brasil. Revista Brasileira de Botânica 25: 237-248.

Cox, G.W. 2004. Adaptation of alien species for dispersal and establishment. Pp. 17-31. In: Cox, G.W. (Aut.). Alien species and evolution - The evolutionary ecology of exotic plants, animals, microbes, and interacting native species. Washington, D.C., Island Press.

Devineau, J.L. 1999. Seasonal rhythms and phenological plasticity of savanna woody species in a fallow farming system (south-west Burkina Faso). Journal of Tropical Ecology 15: 497-513.

Eisikowitch, D. 1986. Morpho-ecological aspects on the pollination of Calotropis procera (Asclepiadaceae) in Israel. Plant Systematics and Evolution 152: 185-194.

El-Ghani, M.M.A. 1997. Phenology of ten common plant species in western Saudi Arabia. Journal of Arid Environments 35: 673-683.

Fournier, L.A. 1974. Un método cuantitativo para la medición de características fenológicas en árboles. Turrialba 24: 422-423.

Godoy, O.; Castro-Díez, P.; Valladares, F. \& Costa-Tenorio, M. 2009. Different flowering phenology of alien invasive species in Spain. Plant Biology 11: 803-811.

Goodwin, B.J.; Mcallister, A.J. \& Fahrig, L. 1999. Predicting invasiveness of plant species based on biological information. Conservation Biology 13: $422-426$.

Kollmann, J. \& Bañuelos, M.J. 2004. Latitudinal trends in growth and phenology of the invasive alien plant Impatiens glandulifera (Balsaminaceae). Diversity and Distributions 10: 377-385.

Lake, J.C. \& Leishman, M.R. 2004. Invasion success of exotic plants in natural ecosystems: the role of disturbance, plant attributes and freedom from herbivores. Biological Conservation 117: 215-226.

Lloret, F.; Médail, F.; Brundu, G.; Camarda, I.; Moragues, E.; Ritas, J.; Lambdon, P. \& Hulme, P.E. 2005. Species attributes and invasion success by alien plants on Mediterranean islands. Journal of Ecology 93: 512-520.

Machado, I.C.; Barros, L.M. \& Sampaio, E.V.S. 1997. Phenology of caatinga species at Serra Talhada, PE, Northeastern Brazil. Biotropica 29: 57-68. 
Newstrom, L.E.; Frankie, G.W. \& Baker, H.G. 1994. A new classification for plant phenology based on flowering patterns in lowland tropical rain forest trees at La Selva, Costa Rica. Biotropica 26: 141-159.

Parsons, W.T. \& Cuthbertson, E.G. 2001. Noxious weeds of Australia. Melbourne, CSIRO Publishing.

Pasiecznik, N.M.; Vall, A.O.M.; Nourissier-Mountou, S.; Danthu, P.; Murch, J.; McHugh, M.J. \& Harris, P.J.C. 2006. Discovery of a life history shift: precocious flowering in a introduced populations of Prosopis. Biological Invasions 8: 1681-1687.

Perglová, I.; Pergl, J. \& Pyšek, P. 2006. Flowering phenology and reproductive effort of the invasive alien plant Heracleum mantegazzianum. Preslia 78: 265-285.
Reichard, S.H. \& Hamilton, C.W. 1997. Predicting invasions of woody plants introduced into North America. Conservation Biology 11: 193-203.

Seghieri, J. \& Simier, M. 2002. Variations in phenology of a residual invasive shrub species in Sahelian fallow savannas, south-west Niger. Journal of Tropical Ecology 18: 897-912.

Singh, J.S. \& Yadava, P.S. 1974. Seasonal variation in composition, plant biomass, and net primary productivity of a tropical grassland at $\mathrm{Ku}-$ rukshetra, India. Ecological Monographs 44: 351-376.

Weber, E. \& Schmid, B. 1998. Latitudinal population differentiation in two species of Solidago (Asteraceae) introduced into Europe. American Journal of Botany 85: 1110-1121. 